\title{
Adsorption behavior of sulfamethazine in an activated sludge process treating swine wastewater
}

\author{
Weiwei Ben ${ }^{1}$, Zhimin Qiang ${ }^{1, *}$, Xiaowei Yin ${ }^{1}$, Jiuhui Qu ${ }^{1}$, Xun Pan ${ }^{2}$ \\ 1. Key Laboratory of Aquatic Science and Technology, Research Center for Eco-Environmental Sciences, Chinese Academy of Sciences, \\ Beijing 100085, China. E-mail: wwben@rcees.ac.cn \\ 2. Foreign Economic Cooperation Office, Ministry of Environmental Protection, Beijing 100035, China
}

\section{A R T I C L E I N F O}

Article history:

Received 13 September 2013

Revised 7 March 2014

Accepted 11 April 2014

Available online 23 June 2014

Keywords:

Sulfonamide antibiotics

Activated sludge

Adsorption

Swine wastewater treatment

\begin{abstract}
A B S T R A C T
Swine wastewater is an important pollution source of antibiotics entering the aquatic environment. In this work, the adsorption behavior of sulfamethazine (SMN), a commonlyused sulfonamide antibiotic, on activated sludge from a sequencing batch reactor treating swine wastewater was investigated. The results show that the adsorption of SMN on activated sludge was an initially rapid process and reached equilibrium after $6 \mathrm{hr}$. The removal efficiency of SMN from the water phase increased with an increasing concentration of mixed liquor suspended solids, while the adsorbed concentration of SMN decreased. Solution $\mathrm{pH}$ influenced both the speciation of SMN and the surface properties of activated sludge, thus significantly impacting the adsorption process. A linear partition model could give a good fit for the equilibrium concentrations of SMN at the test temperatures (i.e., 10,20 and $30^{\circ} \mathrm{C}$ ). The partition coefficient $\left(K_{d}\right)$ was determined to be $100.5 \mathrm{~L} / \mathrm{kg}$ at $20^{\circ} \mathrm{C}$, indicating a quite high adsorption capacity for SMN. Thermodynamic analysis revealed that SMN adsorption on activated sludge was an exothermic process. This study could help to clarify the fate and behavior of sulfonamide antibiotics in the activated sludge process and assess consequent environmental risks arising from sludge disposal as well.
\end{abstract}

(c) 2014 The Research Center for Eco-Environmental Sciences, Chinese Academy of Sciences.

Published by Elsevier B.V.

\section{Introduction}

Antibiotics are constantly being released into the aquatic environment through disposal of human and animal wastes. Even though their detected concentrations are usually at sub- $\mu \mathrm{g} / \mathrm{L}$ levels in natural waters (i.e., surface water and groundwater), the persistence of antibiotics in the aquatic environment exerts a selective pressure on autochthonous bacterial communities, which eventually poses risks to the ecosystem and human health (Baquero et al., 2008; Martínez, 2008).

Antibiotics have been widely used in animal husbandry as therapeutic drugs and feed additives for growth promotion. In China, the annual total use of veterinary antibiotics exceeded 100,000 t in 2010 (http://news.sina.com.cn/c/201011-28/080321546362_4.shtml). However, a significant part of these antibiotics is excreted in feces and urine without absorption and metabolism by animals (Sarmah et al., 2006), which makes the swine wastewater an important pollution source of antibiotics entering the environment. In addition, the practice of applying composted swine wastes to agricultural farmlands may also transfer antibiotics to soils (Chee-Sanford et al., 2009). As a result of overland flow and percolation events, antibiotics can affect surface water and groundwater proximal to concentrated animal feeding operations (CAFOs) (Kay et al., 2005), thus causing the proliferation of antibiotic resistant bacteria. Wei et al. (2011) reported that the concentration of sulfonamides could reach as high as $4.66 \mu \mathrm{g} / \mathrm{L}$, as detected in surface water samples collected from six rivers that were contaminated directly by nearby large-scale CAFOs in Jiangsu Province, China. High percentages of antibiotic resistant bacteria (e.g., Escherichia coli) were found in

\footnotetext{
* Corresponding author. E-mail: qiangz@rcees.ac.cn (Zhimin Qiang).
} 
surface water and groundwater samples collected in the vicinity of large-scale swine farms (Sapkota et al., 2007; Sayah et al., 2005).

Sequencing batch reactor (SBR) has been frequently applied in CAFOs to treat swine wastewater and proved to be effective in decomposing ordinary organic materials as expressed by chemical oxygen demand (COD) (Dosta et al., 2008; Kim et al., 2004). However, to date, the fate and behavior of antibiotics in the SBR for swine wastewater treatment still remain largely unknown. Several studies have reported that adsorption is an important pathway accounting for antibiotic removal from the water phase in activated sludge processes (Halling-Sørensen et al., 1998; Kim et al., 2005). On the one hand, adsorption reduces the concentration of antibiotics in the effluent but increases the residual concentration of antibiotics in the sludge (usually at $\mathrm{mg} / \mathrm{kg}$ level) (Giger et al., 2003); on the other hand, adsorption is also a primary factor influencing the biodegradation of antibiotics, because biodegradation is premised on the ability of antibiotics to interact with sludge particles (Carballa et al., 2004). Furthermore, along with the sludge disposal, the adsorbed antibiotics can be released gradually into the surrounding environment (Halling-Sørensen et al., 1998; Sarmah et al., 2006).

Sulfonamides are one class of veterinary antibiotics most widely used and thus frequently detected in swine wastewater with a broad concentration range (from ng/L to $\mu \mathrm{g} / \mathrm{L}$ ) (Ben et al., 2008; Chen et al., 2012). This class of antibiotics deserves great attention due to their high mobility in the environment (Boxall et al., 2002) and high bioaccumulation by certain plant species (Migliore et al., 1995). The concentration of sulfonamides in sewage sludge was found to range from $13 \mu \mathrm{g} / \mathrm{kg}$ to $2743 \mathrm{mg} / \mathrm{kg}$ (Göbel et al., 2005; Nieto et al., 2010), implying that adsorption plays a crucial role in the fate and behavior of sulfonamides in activated sludge processes.

In this work, sulfamethazine (SMN) was chosen as a model compound to investigate the adsorption behavior of sulfonamides in the activated sludge process for swine wastewater treatment. The kinetics of SMN adsorption on activated sludge was determined through batch experiments. The effects of contact time, concentration of mixed liquor suspended solids (MLSS), $\mathrm{pH}$, and temperature on SMN adsorption were all examined in detail. This study could help to understand the fate and behavior of antibiotics during activated sludge treatment.

\section{Materials and methods}

\subsection{Chemicals}

SMN was purchased from Sigma-Aldrich (St. Louis, MO, USA). Acetonitrile, methanol and dichloromethane (HPLC grade) were obtained from Fisher Scientific (Houston, TX, USA), and were used for sample preparation and liquid chromatography analysis. Other chemicals, of at least analytical grade, were purchased from Beijing Chemical Reagents Company (Beijing, China).

The stock solution of SMN was prepared by dissolving SMN in Milli-Q water at a concentration of $100 \mathrm{mg} / \mathrm{L}$, and could remain stable for more than 1 month in the refrigerator at $4^{\circ} \mathrm{C}$. A $\mathrm{Na}_{2}$ EDTA-McIlvaine buffer solution was prepared by dissolving $21.00 \mathrm{~g}$ of citric acid monohydrate, $17.75 \mathrm{~g}$ of $\mathrm{Na}_{2} \mathrm{HPO}_{4}$, and $60.50 \mathrm{~g}$ of $\mathrm{Na}_{2}$ EDTA. $2 \mathrm{H}_{2} \mathrm{O}$ in $1.625 \mathrm{~L}$ of de-ionized water, with $\mathrm{pH}$ adjusted to $4.00 \pm 0.05$ using $\mathrm{HCl}$ and $\mathrm{NaOH}$ solutions. This buffer solution was prepared freshly prior to each experiment.

\subsection{Activated sludge cultivation}

Activated sludge was originally taken from an aeration tank in the Qinghe municipal sewage treatment plant located in
Beijing, China. The sludge was acclimated in several 10-L SBRs with swine wastewater $(\mathrm{COD} \approx 9000 \mathrm{mg} / \mathrm{L})$ collected from a local large-scale swine feeding farm. Due to the high organic loading, the SBRs were operated with two cycles per day, and each cycle included $15 \mathrm{~min}$ of influent feeding, $4 \mathrm{hr}$ of anoxic phase and $6 \mathrm{hr}$ of aerobic phase, $1.5 \mathrm{hr}$ of sludge settling, and $15 \mathrm{~min}$ of effluent discharge. The sludge retention time (SRT) was about 30 days. After one month, the concentrations of soluble COD (SCOD) in the effluent and MLSS in the reactors reached stability and stayed in the ranges of $473-518$ and $7500-8500 \mathrm{mg} / \mathrm{L}$, respectively. This sludge was then utilized for SMN adsorption experiments. The internal concentration of SMN in the sludge was determined to be $90 \mu \mathrm{g} / \mathrm{kg}$, which could be neglected because it was far below the adsorbed concentrations of SMN as detected in the experiments.

\subsection{Adsorption experiments}

The kinetics of SMN adsorption on activated sludge was first determined. A series of 150-mL Erlenmeyer flasks was filled with $100 \mathrm{~mL}$ aliquots of the fresh mixed liquor taken from the SBRs (MLSS $\approx 8000 \mathrm{mg} / \mathrm{L}$ ). To prevent the biotic elimination of SMN, $0.1 \mathrm{~g}$ of sodium azide $\left(\mathrm{NaN}_{3}\right)$ was added into each flask to inhibit microbial activity. The flasks were shaken on a rotary shaker at $125 \mathrm{r} / \mathrm{min}$ and $20^{\circ} \mathrm{C}$ for $30 \mathrm{~min}$, and then a certain volume of the SMN stock solution $(100 \mathrm{mg} / \mathrm{L})$ was spiked into each flask to achieve initial SMN concentrations of 100, 500 and $3000 \mu \mathrm{g} / \mathrm{L}$. The flasks were shaken again under the same experimental conditions and duplicate samples (100 mL each) were collected into several centrifuge tubes at pre-selected time intervals (i.e., 0.5, 1, 2, 4, 6, 16, and $24 \mathrm{hr}$ ). After centrifugation at $6000 \mathrm{r} / \mathrm{min}$ for $5 \mathrm{~min}$, the supernatants were filtered through $0.45-\mu \mathrm{m}$ polyvinylidene fluoride filters (Millipore, Billerica, MA, USA) and stored at $4^{\circ} \mathrm{C}$ before analysis. The sludge retained at the bottom of the centrifuge tubes was collected and freeze-dried (Boyikang, Model FD1-50, Beijing, China) under vacuum for $24 \mathrm{hr}$, homogenized using a mortar and pestle, and then sieved to obtain particles with a diameter of less than $0.5 \mathrm{~mm}$. The sludge samples were stored in amber glass bottles at $-18^{\circ} \mathrm{C}$ before analysis. The water and sludge samples were analyzed within 2 days after preparation.

Unless otherwise stated, the following experimental conditions were adopted: $\mathrm{T}=20^{\circ} \mathrm{C}, \mathrm{pH}=8.7 \pm 0.2, \mathrm{MLSS} \approx 8000 \mathrm{mg} / \mathrm{L}$, and $\mathrm{SCOD}_{0} \approx 500 \mathrm{mg} / \mathrm{L}$. In the experiments for adsorption isotherms and the effects of MLSS concentration and temperature, the initial SMN concentrations were prepared at 100, 500, 1000, 2000 and $3000 \mu \mathrm{g} / \mathrm{L}$. The influential factors were varied as follows: MLSS = 3200, 5450, 10,400 and 19,160 mg/L; T = 10, 20 and $30^{\circ} \mathrm{C}$; and $\mathrm{pH}=3.0,5.0,7.0,9.0$ and 11.0 (adjusted by $2 \mathrm{~mol} / \mathrm{L}$ $\mathrm{HCl}$ and $\mathrm{NaOH}$ solutions). Different MLSS concentrations were obtained by diluting the settled sludge with the pre-filtered SBR effluent so as to keep the same background solution chemistry. The adsorption experiments were conducted in duplicate, and the relative standard deviations of all data points were determined to be less than $10 \%$. Control experiments with $100 \mathrm{~mL}$ of SBR effluent, which was prefiltered off sludge particles and spiked with a certain initial concentration of SMN, were conducted simultaneously for comparison purposes. 


\subsection{Analysis}

The COD concentration was determined by Hach Method 8000 with a DR5000 spectrophotometer (Hach Co., Loveland, CO, USA). The MLSS concentration was analyzed in accordance with the Standard Methods (APHA, 2005). The SMN concentration in the water phase was determined with liquid chromatography-mass spectrometry (LC-MS) consisting of an Alliance liquid chromatograph (Model 2695) and a single-quadrupole mass spectrometer (ZQ 4000, Waters, Milford, MA, USA). A Waters Symmetry C18 column $(2.1 \times 150 \mathrm{~mm}, 5 \mu \mathrm{m}$; Waters, Milford, MA, USA) was used at a constant temperature of $30^{\circ} \mathrm{C}$. A combination of two mobile phases was programmed with $85 \%$ of $0.2 \%$ (V/V) formic acid in water (mobile phase A) and $15 \%$ of acetonitrile (mobile phase B) for $8 \mathrm{~min}$ at a flow rate of $0.2 \mathrm{~mL} / \mathrm{min}$. The injection volume was $20 \mu \mathrm{L}$. The MS parameters were described in our previous study (Ben et al., 2008). The limit of quantification (LOQ) of SMN in the water phase was $45 \mathrm{ng} / \mathrm{L}$. The SMN analysis in the sludge phase was in accordance with Pan et al. (2011). In brief, the freeze-dried sludge sample (1.0 g) was subjected to ultrasonic liquid extraction and solid phase extraction successively, and then the SMN concentration was measured with LC-MS. The LOQ of SMN in the sludge phase was $12 \mu \mathrm{g} / \mathrm{kg}$, which was sufficiently low for the detection of residual SMN in activated sludge.

\section{Results and discussion}

\subsection{Inhibition of sludge bioactivity}

The SMN concentration could remain stable for $24 \mathrm{hr}$ in the SBR effluent pre-filtered off suspended solids (SS) particles,

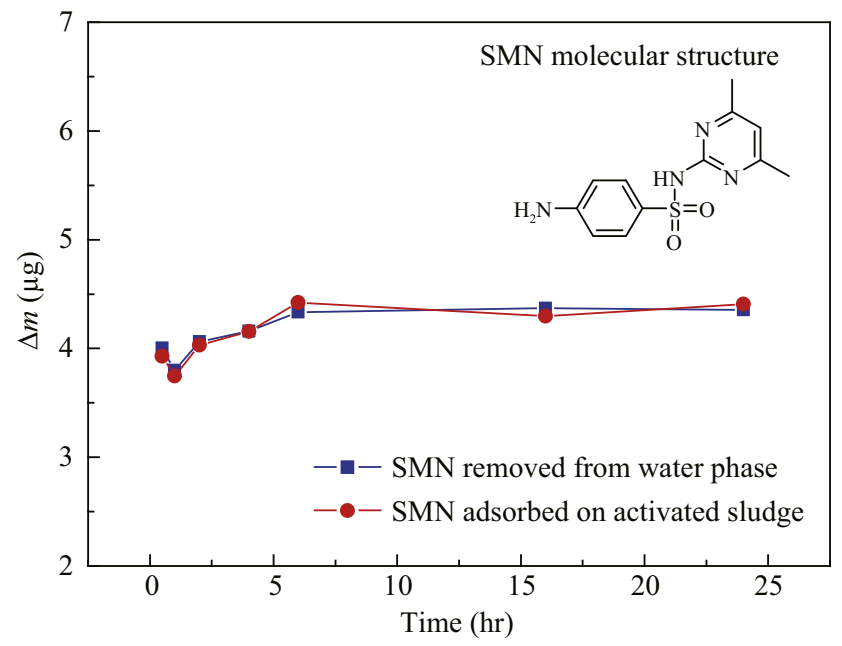

Fig. 1 - Comparison between the amounts of SMN removed from water phase and adsorbed on activated sludge (biologically inhibited). Experimental conditions: $\mathrm{T}=20^{\circ} \mathrm{C}$, $\mathrm{pH}=8.7 \pm 0.2, \mathrm{MLSS} \approx 8000 \mathrm{mg} / \mathrm{L}, \mathrm{SCOD}_{0} \approx 500 \mathrm{mg} / \mathrm{L}$, and $C_{0, \text { SMN }}=100 \mu \mathrm{g} / \mathrm{L}$. SMN: sulfamethazine; MLSS: mixed liquor suspended solids; $\mathrm{SCOD}_{\mathrm{o}}$ : the initial concentration of soluble chemical oxygen demand; $\mathrm{C}_{\mathrm{o}, \mathrm{SMN}}$ : the initial concentration of SMN. indicating that the volatilization and hydrolysis of SMN were insignificant. The effect of the biological inhibitor $\left(\mathrm{NaN}_{3}, 1.0 \mathrm{~g} / \mathrm{L}\right)$ on microbial activity was first examined. Fig. 1 shows that the amount of SMN removed from the water phase was equal to that adsorbed on the activated sludge, which demonstrates that the biological activity of activated sludge was completely inhibited. Furthermore, this result also validated the applicability of the two analytical methods used for SMN detection in the liquid and sludge phases, respectively (Ben et al., 2008; Pan et al., 2011).

\subsection{Adsorption kinetics and isotherms}

The SMN adsorption kinetics on activated sludge was studied at $20^{\circ} \mathrm{C}$ with initial SMN concentrations ranging from 100 to $3000 \mu \mathrm{g} / \mathrm{L}$. As shown in Fig. 2, a rapid initial adsorption was observed in the first $0.5 \mathrm{hr}$, and then a slight release of the sludge-bound SMN occurred, which caused a small drop of the removal efficiency. After $1 \mathrm{hr}$, the adsorbed SMN amount increased continuously till it reached adsorption equilibrium at $6 \mathrm{hr}$, when the maximum adsorbed concentrations were $5.3,23.8$ and $134.6 \mathrm{mg} / \mathrm{kg}$ SS in correspondence with the initial SMN concentrations of 100,500 and $3000 \mu \mathrm{g} / \mathrm{L}$, respectively. Further extending the contact time to $24 \mathrm{hr}$ hardly enhanced the removal of SMN.

The experimental data of SMN adsorption on activated sludge at 10,20 and $30^{\circ} \mathrm{C}$ fit well to the Freundlich model (Table 1), with the correlation coefficients $\left(R^{2}\right)$ being all greater than 0.98 (Table 2). Further fitting with the Linear model $\left(R^{2}>0.99\right)$ indicated that the SMN adsorption could be simplified as partitioning between the water and sludge phases because of the relatively low adsorbate concentrations (Table 2). The partition coefficient, $K_{d}$, was determined to be $100.5 \mathrm{~L} / \mathrm{kg}$ at $20^{\circ} \mathrm{C}$, manifesting a quite high adsorption capacity of activated sludge for SMN. The $K_{d}$ values can be used to predict the adsorption behavior of SMN in the SBR treatment process.

\subsection{Effects of MLSS concentration and $p H$}

As shown in Fig. 3, the MLSS concentration significantly influenced the SMN adsorption process. As the MLSS concentration increased from 3200 to $19,160 \mathrm{mg} / \mathrm{L}$, the $K_{d}$ value decreased from 324.5 to $50.2 \mathrm{~L} / \mathrm{kg}$ (Fig. 3a). Because of the solids concentration effect commonly known to occur in the adsorption process (Voice et al., 1993), the adsorbed concentration of SMN decreased with an increase in the MLSS concentration (Fig. 3b). For full-scale biological treatment processes, the SRT is an important factor closely related to the MLSS concentration and thus affects the removal efficiency of antibiotics. A longer SRT generally leads to a higher MLSS concentration, and consequently an increased total amount of adsorbed antibiotics. Therefore, a long SRT usually favors the removal of SMN from the water phase in the activated sludge process. Kreuzinger et al. (2004) reported that the removal efficiency of sulfamethoxazole from wastewater treatment plants increased from 33 to $62 \%$ as the SRT increased from 23.6 to 96.0 days.

Fig. 4 a shows that the removal efficiency of SMN increased from 34.2 to $39.0 \%$ as the $\mathrm{pH}$ increased from 3.0 to 5.0; however, 


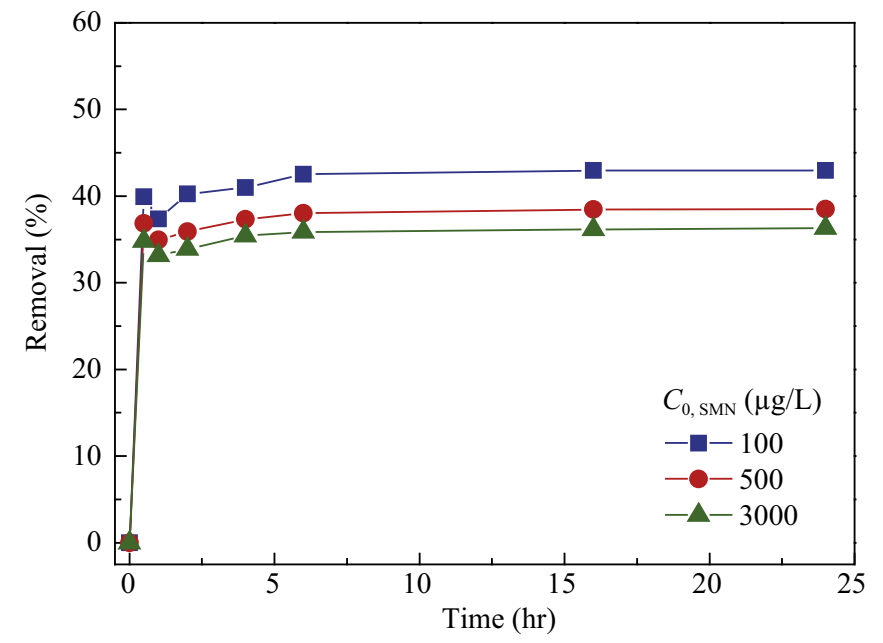

Fig. 2 - Removal of SMN by sludge adsorption as a function of contact time. Experimental conditions: $\mathrm{T}=20^{\circ} \mathrm{C}, \mathrm{pH}=8.7 \pm 0.2$, $\mathrm{MLSS} \approx 8000 \mathrm{mg} / \mathrm{L}, \mathrm{SCOD}_{0} \approx 500 \mathrm{mg} / \mathrm{L}$.

further increasing $\mathrm{pH}$ led to a continuous decrease in the SMN removal. The mechanism for SMN adsorption on activated sludge may include both electrostatic interactions and partition into the organic carbon of activated sludge, as illustrated in Fig. 4b. The surface of activated sludge was always negatively charged in the tested $\mathrm{pH}$ range (i.e., 3.0-11.0) since its $\mathrm{pH}_{\mathrm{zpc}}$ (i.e., zero point of charge) is about 2.7-2.9 (Wang et al., 2000; Weng et al., 2001a, 2001b). The SMN ionization constants ( $\mathrm{pK}_{\mathrm{a}, 1}$ and $\mathrm{pK}_{\mathrm{a}, 2}$ ) are 2.07 and 7.49, respectively (Qiang and Adams, 2004). The speciation of SMN as a function of $\mathrm{pH}$ shows that SMN mainly existed in the neutral form around pH 5.0 (Fig. 4b). As the $\mathrm{pH}$ increased to 9.0, the anionic form became prevalent, which inhibited the SMN adsorption due to electrostatic repulsion. However, the removal efficiency of SMN decreased by no more than $25 \%$ as the $\mathrm{pH}$ increased from 5.0 to 11.0 , implying that electrostatic force could not play a critical role in the adsorption process. Hence, the partition of SMN into the organic carbon of activated sludge was likely to play a primary role. The adsorption coefficient normalized by organic carbon $\left(K_{\mathrm{OC}}\right)$ was reported to range from 82 to $208 \mathrm{~L} / \mathrm{kg}$ for SMN in soils (Thiele-Bruhn, 2003), revealing an obvious partition of SMN into organic matter. Activated sludge usually consists of about $40 \%$ of organic matter (Göbel et al., 2005). At pH 11.0, the SCOD concentration increased markedly (Fig. 4a), which denotes the dissolution of organic matter from the sludge phase into the water phase and a consequent decrease in the SMN removal.

Li and Zhang (2010) found that the adsorption of two sulfonamides (i.e., sulfadiazine and sulfamethoxazole) on

\section{Table 1 - Isotherm and thermodynamic equations used to simulate SMN adsorption on activated sludge.}

Equations

Freundlich isotherm

$q_{\mathrm{e}}=K_{\mathrm{f}} C_{\mathrm{e}}{ }^{1 / n}$

Linear partition

$\mathrm{K}_{\mathrm{d}}=q_{\mathrm{e}} / \mathrm{C}_{\mathrm{e}}$

Thermodynamics

$\Delta G^{\circ}=-R T \ln K$

$\ln K=-\Delta H^{\circ} / R T+\Delta S^{\circ} / R$

\section{Parameters}

$q_{\text {e }}(\mathrm{mg} / \mathrm{kg})$ : equilibrium adsorbent-phase concentration of adsorbate

$\mathrm{C}_{\mathrm{e}}(\mathrm{mg} / \mathrm{L})$ : equilibrium aqueous concentration of adsorbate; $\mathrm{K}_{\mathrm{f}}\left((\mathrm{mg} / \mathrm{L})(\mathrm{L} / \mathrm{mg})^{1 / n}\right)$ : Freundlich adsorption capacity parameter; $n$ : Freundlich adsorption intensity parameter, unitless $K_{d}(\mathrm{~L} / \mathrm{kg})$ : partition coefficient

$\Delta G^{0}(\mathrm{~kJ} / \mathrm{mol})$ : Gibbs free energy

$\Delta H^{0}(\mathrm{~kJ} / \mathrm{mol})$ : standard enthalpy change

$\Delta S^{0}(\mathrm{~kJ} /(\mathrm{mol} \cdot \mathrm{K}))$ : standard entropy change

$R\left(8.314 \times 10^{-3} \mathrm{~kJ} /(\mathrm{mol} \cdot \mathrm{K})\right)$ : universal gas constant

$\mathrm{T}(\mathrm{K})$ : absolute temperature

$\mathrm{K}(\mathrm{L} / \mathrm{kg})$ : equilibrium constant (equal to $\mathrm{K}_{\mathrm{d}}$ in this study)

Table 2 - Simulated isotherm and thermodynamic parameters for SMN adsorption on activated sludge.

\begin{tabular}{|c|c|c|c|c|c|c|c|c|}
\hline \multirow[t]{3}{*}{$\mathrm{T}\left({ }^{\circ} \mathrm{C}\right)$} & \multicolumn{5}{|c|}{ Isotherm parameters } & \multicolumn{3}{|c|}{ Thermodynamic parameter } \\
\hline & \multicolumn{3}{|c|}{ Freundlich model } & \multicolumn{2}{|c|}{ Linear model } & & & \\
\hline & $K_{\mathrm{f}}$ & $1 / n$ & $R^{2}$ & $K_{d}$ & $R^{2}$ & $\begin{array}{c}\Delta G^{0} \\
(\mathrm{~kJ} / \mathrm{mol})\end{array}$ & $\begin{array}{c}\Delta S^{0} \\
(\mathrm{~J} /(\mathrm{mol} \cdot \mathrm{K}))\end{array}$ & $\begin{array}{c}\Delta H^{0} \\
(\mathrm{~kJ} / \mathrm{mol})\end{array}$ \\
\hline 10 & 166.7 & 1.00 & 0.999 & 166.7 & 0.999 & -12.04 & -90.37 & -37.64 \\
\hline 20 & 171.3 & 0.93 & 0.997 & 100.5 & 0.992 & -9.73 & & \\
\hline 30 & 1.3 & 1.50 & 0.988 & 57.9 & 0.998 & -7.76 & & \\
\hline
\end{tabular}



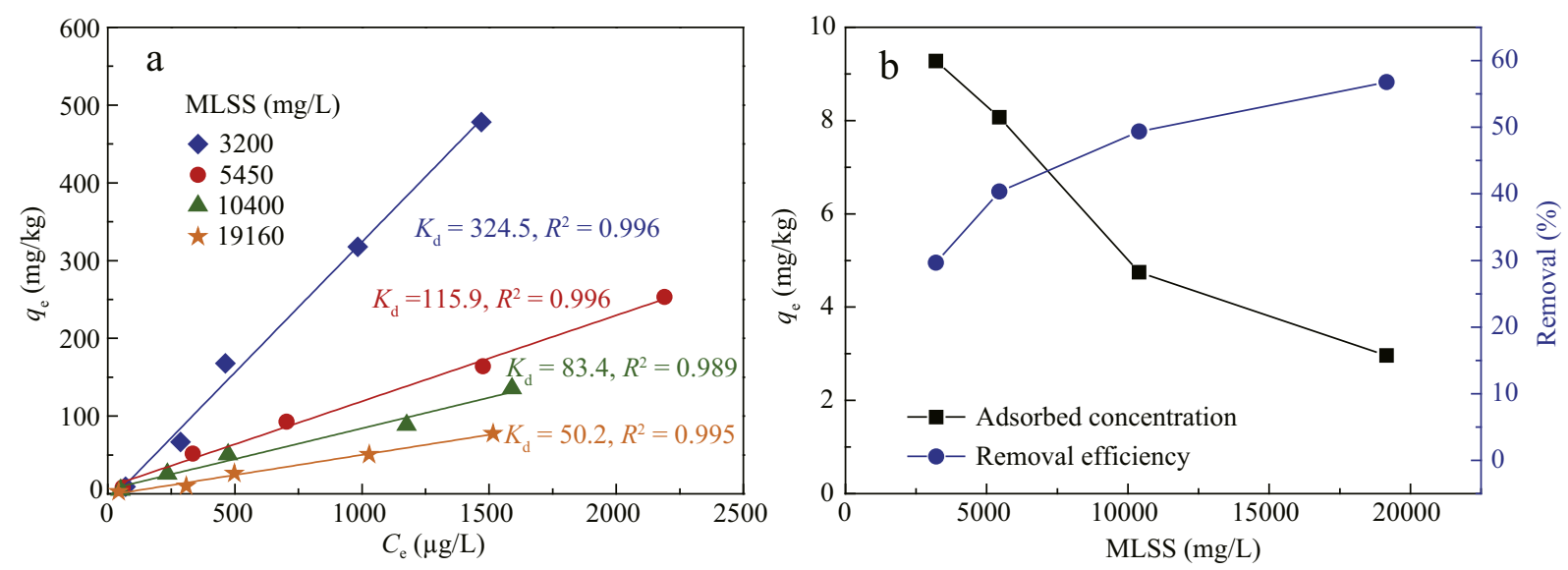

Fig. 3 - SMN adsorption on activated sludge at different MLSS concentrations. (a) Linear partition curves; (b) adsorbed concentration on sludge and removal efficiency of $\operatorname{SMN}\left(C_{0}, \mathrm{SMN}=100 \mu \mathrm{g} / \mathrm{L}\right)$. Experimental conditions: $\mathrm{T}=20^{\circ} \mathrm{C}, \mathrm{pH}=8.7 \pm 0.2$, $\mathrm{SCOD}_{0} \approx 500 \mathrm{mg} / \mathrm{L}$, and $\mathrm{C}_{0, \mathrm{SMN}}=100,500,1000,2000$, and $3000 \mu \mathrm{g} / \mathrm{L}$.

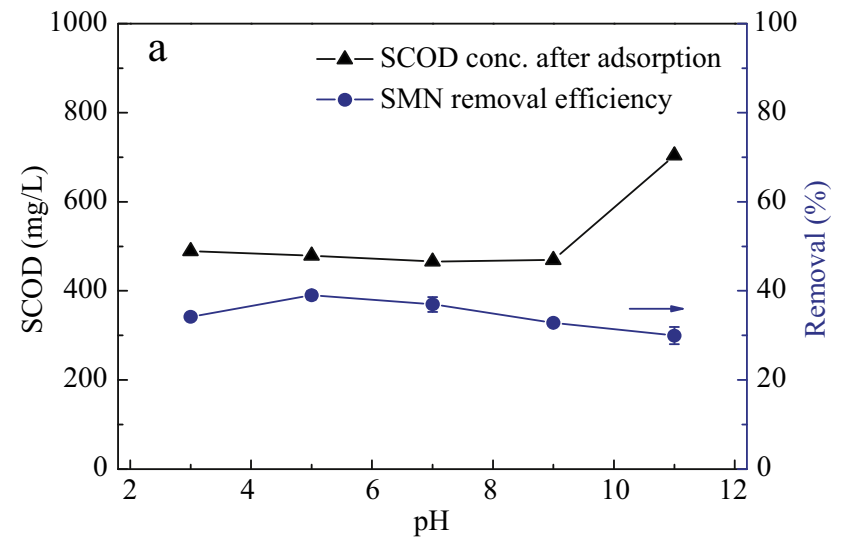

b Electrostatic interactions/hydrogen bonding
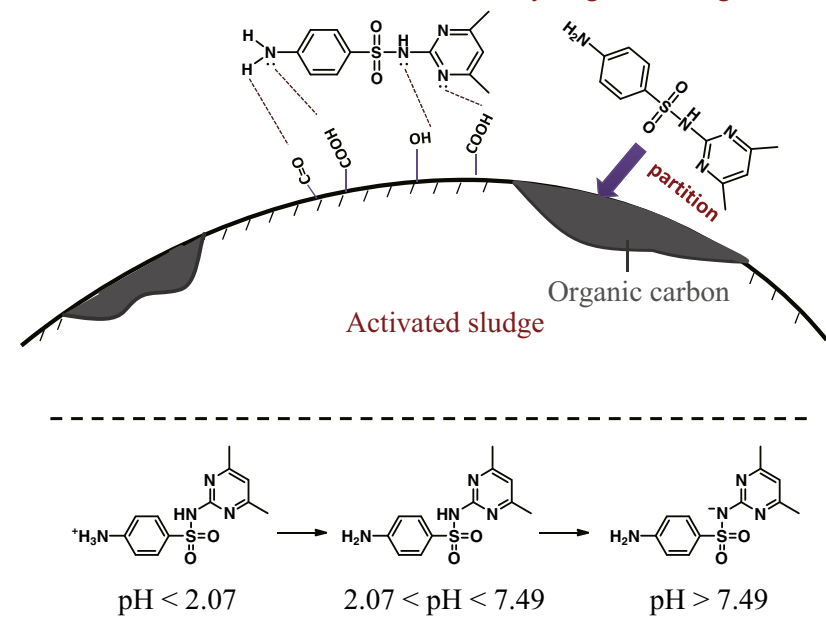

Fig. 4 - SMN adsorption on activated sludge at different $\mathrm{pH}$ values. (a) SMN removal and SCOD concentration change as a function of $\mathrm{pH}$; (b) proposed mechanism for SMN adsorption onto activated sludge and SMN speciation under various pH conditions. Experimental conditions: $\mathrm{T}=20^{\circ} \mathrm{C}$, $\mathrm{SCOD}_{0} \approx 500 \mathrm{mg} / \mathrm{L}, \mathrm{MLSS} \approx 8000 \mathrm{mg} / \mathrm{L}$, and $\mathrm{C}_{0, \mathrm{SMN}}=500 \mu \mathrm{g} / \mathrm{L}$. activated sludge could be neglected. They collected the fresh mixed liquor from the aeration tanks of two wastewater treatment plants, with MLSS concentrations of 2210 and $2572 \mathrm{mg} / \mathrm{L}$ and SRTs of 12 and 7 days, respectively. The different results observed could probably arise from the much higher MLSS concentration adopted in this work (i.e., $8000 \mathrm{mg} / \mathrm{L}$ ). Moreover, a much longer SRT (i.e., 30 days in this work) could result in a more hydrophobic surface for the activated sludge (Liss et al., 2002), thus favoring SMN adsorption. Another possibility lies in that the swine wastewater contained a large variety of organic materials (e.g., proteins, lipids) and nutrients, thus the acclimated activated sludge could have more carboxylic and phenolic moieties to form hydrogen bonds with the amine groups of SMN (Thiele-Bruhn and Aust, 2004; Ben et al., 2013).

\subsection{Adsorption thermodynamics}

Fig. $5 \mathrm{a}$ shows that the $\mathrm{K}_{\mathrm{d}}$ value decreased with increasing temperature from 10 to $30^{\circ} \mathrm{C}$, indicating that a lower temperature was more favorable for SMN adsorption on activated sludge. Further analysis gave the following Arrhenius equation: $\ln K_{d}=4527.88 / T-10.87\left(R^{2}=0.996\right)$ (Fig. 5b). The thermodynamic parameters are listed in Table 1 . The negative $\Delta G^{\circ}$ values indicated that the SMN adsorption on activated sludge could proceed spontaneously, and the values of $\Delta H^{\circ}(-37.64 \mathrm{~kJ} / \mathrm{mol})$ and $\Delta S^{\circ}(-90.37 \mathrm{~J} /(\mathrm{mol} \cdot \mathrm{K}))$ revealed the exothermic and physical nature of this adsorption process.

\section{Conclusions}

SMN adsorption on activated sludge was an initially rapid process and reached equilibrium at $6 \mathrm{hr}$. The linear partition model could fit the adsorption data well at equilibrium. The obtained partition coefficient $\left(K_{d}\right)$ demonstrated a quite high adsorption capacity of activated sludge for SMN. The total amount of adsorbed SMN increased with an increasing MLSS 

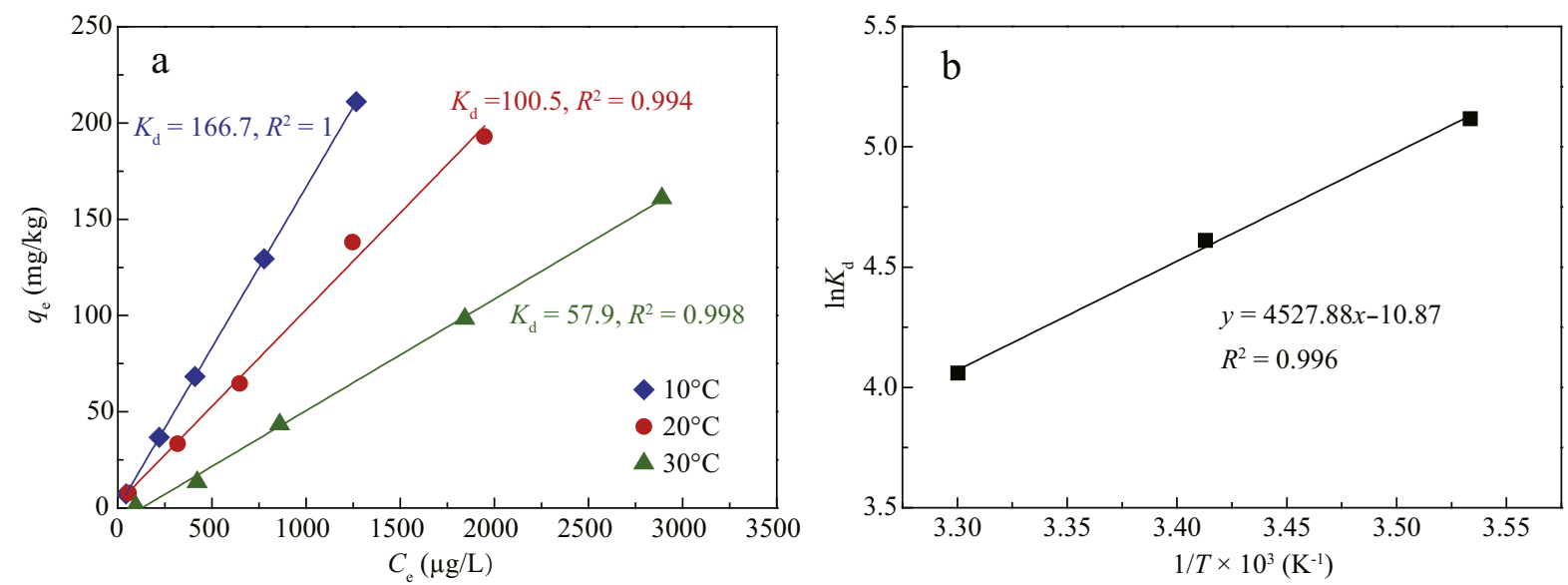

Fig. 5 - SMN adsorption by activated sludge at different temperatures. (a) Linear partition curves; (b) Arrhenius equation plot. Experimental conditions: $\mathrm{pH}=8.7 \pm 0.2, \mathrm{SCOD}_{0} \approx 500 \mathrm{mg} / \mathrm{L}, \mathrm{MLSS} \approx 8000 \mathrm{mg} / \mathrm{L}$, and $\mathrm{C}_{0}$, $\mathrm{sMN}=100,500,1000,2000$, and $3000 \mu \mathrm{g} / \mathrm{L}$.

concentration, indicating that the SRT was an important factor influencing SMN adsorption in the activated sludge process. The increase of $\mathrm{pH}$ from 5.0 to 11.0 decreased the removal efficiency of SMN by no more than $25 \%$, implying that the partition of SMN into the organic carbon of activated sludge was likely to play a primary role rather than electrostatic interactions. Thermodynamic data showed that SMN adsorption on activated sludge was a spontaneous and exothermic process. This study helps to understand the adsorption behavior of sulfonamides in the activated sludge process for swine wastewater treatment. Further research is required to clarify the distribution pattern of antibiotic-resistant genes in activated sludge so as to assess the environmental risks associated with the release of antibiotics during sludge disposal.

\section{Acknowledgments}

The work was financially supported by the National Natural Science Foundation of China (Nos. 21107127 and 51221892), the Ministry of Housing and Urban-rural Development of China (No. 2012ZX07313-001-07), and the State Key Laboratory of Environmental Aquatic Chemistry (No. 10Y06ESPCR).

\section{R E F E R E N C E S}

APHA, 2005. Standard Methods for the Examination of Water and Wastewater 21st Ed. American Public Health Association, Washington DC, USA.

Baquero, F., Martinez, J., Canton, R., 2008. Antibiotics and antibiotic resistance in water environments. Curr. Opin. Biotechnol. 19 (3), 260-265.

Ben, W., Qiang, Z., Adams, C., Zhang, H., Chen, L., 2008. Simultaneous determination of sulfonamides, tetracyclines and tiamulin in swine wastewater by solid-phase extraction and liquid chromatography-mass spectrometry. J. Chromatogr. A 1202 (2), 173-180.

Ben, W.W., Pan, X., Qiang, Z.M., 2013. Occurrence and partition of antibiotics in the liquid and solid phases of swine wastewater from concentrated animal feeding operations in Shandong Province, China. Environ. Sci.: Process. Impacts 15 (4), 870-875.

Boxall, A.B.A., Blackwell, P.A., Cavallo, R., Kay, P., Tolls, J., 2002. The sorption and transport of a sulfonamide antibiotic in soil systems. Toxicol. Lett. 131 (1-2), 19-28.

Carballa, M., Omil, F., Lema, J.M., Llompart, M., García-Jares, C., Rodríguez, I., et al., 2004. Behavior of pharmaceuticals, cosmetics and hormones in a sewage treatment plant. Water Res. 38 (12), 2918-2926.

Chee-Sanford, J.C., Mackie, R.I., Koike, S., Krapac, I.G., Lin, Y., Yannarell, A.C., et al., 2009. Fate and transport of antibiotic residues and antibiotic resistance genes following land application of manure waste. J. Environ. Qual. 38 (3), 1086-1108.

Chen, Y.S., Zhang, H.B., Luo, Y.M., Song, J., 2012. Occurrence and dissipation of veterinary antibiotics in two typical swine wastewater treatment systems in east China. Environ. Monit. Assess. 184 (4), 2205-2217.

Dosta, J., López-Palau, S., Mata-Álvarez, J., 2008. Study of the biological $\mathrm{N}$ removal over nitrite in a physico-chemical biological treatment of digested pig manure in a SBR. Water Sci. Technol. 58 (1), 119-125.

Giger, W., Alder, A.C., Golet, E.M., Kohler, H.E., McArdell, C.S., Molnar, E., et al., 2003. Occurrence and fate of antibiotics as trace contaminants in wastewaters, sewage sludges, and surface waters. Chimia 57 (9), 485-491.

Göbel, A., Thomsen, A., McArdell, C.S., Joss, A., Giger, W., 2005. Occurrence and sorption behavior of sulfonamide, macrolide, and trimethoprim in activated sludge treatment. Environ. Sci. Technol. 39 (11), 3981-3989.

Halling-Sørensen, B., Nielsen, S.N., Lanzky, P.F., Ingerslev, F., Lutzhoft, H.C.H., Jorgensen, S.E., 1998. Occurrence, fate and effects of pharmaceutical substances in the environment - a review. Chemosphere 36 (2), 357-394.

Kay, P., Blackwell, P.A., Boxall, A.B.A., 2005. Transport of veterinary antibiotics in overland flow following the application of slurry to arable land. Chemosphere 59 (7), 951-959.

Kim, J., Chen, M., Kishida, N., Sudo, R., 2004. Integrated real-time control strategy for nitrogen removal in swine wastewater treatment using sequencing batch reactors. Water Res. 38 (14-15), 3340-3348.

Kim, S., Eichhorn, P., Jensen, J.N., Weber, A.S., Aga, D.S., 2005. Removal of antibiotics in wastewater: effect of hydraulic and solid retention times on the fate of tetracycline in the activated sludge process. Environ. Sci. Technol. 39 (15), 5816-5823. 
Kreuzinger, N., Clara, M., Strenn, B., Kroiss, H., 2004. Relevance of the sludge retention time (SRT) as design criteria for wastewater treatment plants for the removal of endocrine disruptors and pharmaceuticals from wastewater. Water Sci. Technol. 50 (5), 149-156.

Li, B., Zhang, T., 2010. Biodegradation and adsorption of antibiotics in the activated sludge process. Environ. Sci. Technol. 44 (9), 3468-3473.

Liss, S.N., Liao, B.Q., Droppo, I.G., Allen, D.G., Leppard, G.G., 2002. Effect of solids retention time on floc structure. Water Sci. Technol. 46 (1-2), 431-438.

Martínez, J.L., 2008. Antibiotics and antibiotic resistance genes in natural environments. Science 321 (5887), 365-367.

Migliore, L., Brambilla, G., Cozzolino, S., Gaudio, L., 1995. Effect on plants of sulphadimethoxine used in intensive farming (Panicum miliaceum, Pisum sativum and Zea mays). Agric. Ecosyst. Environ. 52 (2-3), 103-110.

Nieto, A., Borrull, F., Pocurull, E., Marcé, R.M., 2010. Occurrence of pharmaceuticals and hormones in sewage sludge. Environ. Toxicol. Chem. 29 (7), 1484-1489.

Pan, X., Qiang, Z.M., Ben, W.W., Chen, M.X., 2011. Simultaneous determination of three classes of antibiotics in the suspended solids of swine wastewater by ultrasonic extraction, solid-phase extraction and liquid chromatography-mass spectrometry. J. Environ. Sci. 23 (10), 1729-1737.

Qiang, Z.M., Adams, C., 2004. Potentiometric determination of acid dissociation constants $\left(\mathrm{pK}_{\mathrm{a}}\right)$ for human and veterinary antibiotics. Water Res. 38 (12), 2874-2890.

Sapkota, A.R., Curriero, F.C., Gibson, K.E., Schwab, K.J., 2007. Antibiotic-resistant enterococci and fecal indicators in surface water and groundwater impacted by a concentrated swine feeding operation. Environ. Health Perspect. 115 (7), 1040-1045.
Sarmah, A.K., Meyer, M.T., Boxall, A.B.A., 2006. A global perspective on the use, sales, exposure pathways, occurrence, fate and effects of veterinary antibiotics (VAs) in the environment. Chemosphere 65 (5), 725-759.

Sayah, R.S., Kaneene, J.B., Johnson, Y., Miller, R., 2005. Patterns of antimicrobial resistance observed in Escherichia coli isolates obtained from domestic- and wild-animal fecal samples, human septage, and surface water. Appl. Environ. Microbiol. 71 (3), 1394-1404.

Thiele-Bruhn, S., 2003. Pharmaceutical antibiotic compounds in soils - a review. J. Plant Nutr. Soil Sci. 166 (2), 145-167.

Thiele-Bruhn, S., Aust, M., 2004. Effects of pig slurry on the sorption of sulfonamide antibiotics in soil. Arch. Environ. Contam. Toxicol. 47 (1), 31-39.

Voice, T.C., Rice, C.P., Weber, W.J., 1993. Effect of solids concentration on the sorptive partitioning of hydrophobic pollutants in aquatic systems. Environ. Sci. Technol. 17 (9), 513-518.

Wang, J.M., Huang, C.P., Allen, H.E., 2000. Surface physical-chemical characteristics of sludge particulates. Water Environ. Res. 72 (5), 545-553.

Wei, R., Ge, F., Huang, S., Chen, M., Wang, R., 2011. Occurrence of veterinary antibiotics in animal wastewater and surface water around farms in Jiangsu Province, China. Chemosphere 82 (10), 1408-1414.

Weng, C.H., Chiang, P.C., Chang, E.E., 2001a. Adsorption characteristics of $\mathrm{Cu}^{\text {III }}$ on to industrial wastewater sludges. Adsorpt. Sci. Technol. 19 (2), 143-157.

Weng, C.H., Chiang, P.C., Chang, E.E., 2001b. Characteristics of new coccine dye adsorption onto digested sludge particulates. Water Sci. Technol. 44 (10), 279-284. 